INTERNATIONAL JOURNAL OF RESEARCHES IN BIOSCIENCES, AGRICULTURE AND TECHNOLOGY (c) VISHWASHANTI MULTIPURPOSE SOCIETY (Global Peace Multipurpose Society) R. No. MH-659/13(N) www.vmsindia.org

\title{
LOW COST NATURAL AGRICULTURE BYPRODUCT ADSORBENTS USED TO REMOVE HEAVY METAL FROM WASTEWATER
}

\author{
Sanjay V. Kolhe \\ P. G. Department of Chemistry, \\ Shri Shivaji Arts, Commerce \&Science College, Akot \\ Email; -drsanjaykolhe22@gmail.com
}

\begin{abstract}
Adsorption is a process that occurs when a gas or liquid solute accumulates on the surface of a solid or a liquid (adsorbent), forming a molecular or atomic film. Adsorption is operative in most natural physical, biological, and chemical systems, and is widely used in industrial applications such as activated charcoal, synthetic resins and water purification. Among these methods, adsorption is currently considered to be very suitable for wastewater treatment because of its simplicity and cost effectiveness. Adsorption is commonly used technique for the removal of metal ions from various industrial effluents. Activated carbon is the most widely used adsorbent.
\end{abstract}

Keywords- Adsobtion, metal, technique, Cd (II), Pearl millet, Chestnut

\section{INTRODUCTION:}

Heavy metals in water resources are one of the most important environmental problems of countries. Due to modernization, the industrial use of metals especially, heavy metals, has risen alarmingly, thus becoming of prior concern because of their toxicity to flora and fauna. Recovery of heavy metals from industrial waste streams is becoming increasingly important as society realizes the necessity for recycling and conservation of essential metals [1]. The intensification of industrial activity and environmental stress greatly contributes to the significant rise of heavy metal pollution in water resources making threats on terrestrial and aquatic life.

The toxicity of metal pollution is slow and interminable, as these metal ions are non bio-degradable. Until now, various methods of removing of these metals have been considered, including the use of low price materials ${ }^{[2,3]}$. The use of natural materials for heavy metal removal has become a concern in all countries. Natural materials that are available in large quantities or certain waste from agricultural processes may have potential a slow cost adsorbents, as they represent unused resources, widely available and are environmentally friendly [4]. To see the decrease of polluted water, most researches were concentrated with treatment of heavy metals from industrial wastewater. This uses normal material to removal metals from different sides because it is valid largely in agriculture processes in addition to their low price as adsorbent materials [5].

It is important to remove the heavy metals from the resources the various methods are available to remove poisonous elements are Chemical precipitation, Ion exchange, Reverse osmosis, Electro dialysis, Ultra filtration, Coangulations', Flotation, and Adsorption.

Adsorption is a simple and cost effective technique and hence it is widely used for wastewater treatment. It is affected by factors like Contact time, Adsorbent Loading, Temperature, Concentration of adsorbate, $\mathrm{pH}$ of solution etc. Adsorption is one of the most convenient technique for the removal of heavy metals from waste water having advantages over the conventional methods because of its simple design and sludge free environment [6-9].

\section{REVIEW OF LITERATURE:}

Literature survey shows that various low cost natural adsorbents have been used to remove metal from wastewater. Some of them are listed as follows:

Adsorbent Corn corb shread was tested for their ability to absorb individual dyes and dye mixture in solutions up to 70 to $75 \%$ colour removal was achieved from $500 \mathrm{ppm}$ dye solutions at room temperature [10]. Corn Corbis used to remove $\mathrm{Cu}(\mathrm{II}), \mathrm{Cr}(\mathrm{VI}), \mathrm{Ni}(\mathrm{II})$ [1113].Coconut shell dust was one of the agriculture waste products obtained used as adsorbent in wastewater treatment. Its all year round availability and its abundance in the environment makes it's a good source of adsorbent for metal ion removal from aqueous solutions [14-15]. hence coconut shell was a good adsorbent are also used to removed $\mathrm{Ni}^{2+}, \mathrm{Pb}^{2+}$,

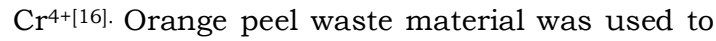
removed $\mathrm{Cr}, \mathrm{Cd}$ and $\mathrm{Co}$ metal ions [18].Prosopis Juliflora Leaf Powder was used to remove only $\mathrm{Cu}^{2+}$ not for other metal removal [19]. $\mathrm{Cr}^{4+}$ is removed with the help of Jambhool Leaf Powder[20]. Pistachio Shells was found to be excellent $\mathrm{Zn}^{2+[21]}$. Tea Leaves has wide 
application to remove $\mathrm{Pb}, \mathrm{Fe}, \mathrm{Zn}$ and $\mathrm{Ni}$ metal ions ${ }^{[22]}$. Also Saffron Leaves were help to remove $\mathrm{Cu}, \mathrm{Pb}$, and Cdmetal ions [23].

It was found that some simple and low-cost chemical modifications resulted in increasing the absorption capacity of raw rice husk (RRH) has been studied [24].Rice Husk is also used to remove $\mathrm{Ni}^{2+}$ and $\mathrm{Zn}^{2+}$ but rice husk has higher efficiency to removed cadmium.

Walnut Shell was used to remove $\mathrm{Cu}^{2+}, \mathrm{Cr}^{4+}$ from waste water to reduce their toxicity [25].

Average concentration of cadmium in the earth's crust is between 0.1 and 0.5 parts per million. Cadmium is found as an impurity in zinc carbonate ${ }^{[26]}$ and also occurs as a minor component in most of the zinc ores. Cadmium is also present in the wet process acid (WPA) used for the fertilizer manufacture from phosphate rock and there are some reports where adsorption process have been applied to remove it [27-28].

Cadmium is extremely toxic even in low concentration and will bio accumulate in organism and ecosystem. Building up of cadmium level in water, soil and air has been occurring particularly in industrial area. Smelting and refining of metals and the plants that makes cadmium product increased the cadmium level in air. Some sources of phosphate fertilizer contain cadmium in amounts of up to $100 \mathrm{mg} / \mathrm{kg}$ which leads to an increased in the concentration of cadmium in the soil. The cadmium poisoning caused softening of the bones and kidney failure termed as itai-itai disease. Compounds containing cadmium are also carcinogenic. Although cadmium is toxic in nature, cadmium is used to block calcium channels in chicken neurons and cadmium iodide is used as a medication to treat enlarged joints, scrofulous glands and chilblains. Cadmium is a widespread, naturally occurring, element that is present in soils, rocks, waters, plants and animals. Phosphorus containing fertilizers can contain high levels of cadmium depending upon the source of rock phosphate used in manufacturing. Cadmium can accumulate in humans and high levels can affect human health, through bone disease and kidney damage. The general advantage of solvent extraction is its efficacy for recovering the metal ions at high concentration with high selectivity and is suitable for continuous operation.

Due to growing demand of high purity metal, concern over environmental issues, the need for lower production cost continuous depletion of high grade ores which has resulted in the treatment of ores of lower grade and greater complexity, solvent extraction has becomes an important hydrometallurgical tool. Recovery and recycling of metals will conserve the natural resources to meet the future demand of materials also reduce the environmental pollution. Among the available processing alternatives, solvent extraction is the technique that not only meets the strict environmental regulations and also high purity value added products would be produced [3132].

Hence this study was carried out to explore the utility of waste material like Pearl millet and water chestnut to remove the $\mathrm{Cd}^{2+}$ by adsorption process.

\section{METHODOLOGY:}

\section{Direct titration}

The solution containing the $100 \mathrm{ppm}$ of Cadmium (II) was buffered by $10 \mathrm{~mL}$ of ammonical solution of $\mathrm{pH}=10$ and titrated directly with the standard EDTA solution of 100 ppm using solochrome black $\mathrm{T}$ as an indicator. The titration was continued until the color changes from red to blue.

Preparation of bio adsorbent using pearl millet -

Pearl millet dust was collected from local agricultural farm. It was oven dried at $110^{\circ} \mathrm{C}$ overnight then it is added with conc. sulphuric acid weight/volume ratio $1: 1$. Then resulting black product was washed with water until free from excess acid and dried at $150^{\circ} \mathrm{C}$. The carbon product obtained was ground well to fine particles which is used for all

Experiments.

Preparation of bio adsorbent using water chestnut -

Trepanations was collected from local market washed with tap water to removed the dust and debris attached to it and then washed with distilled water. The washed was dried in sunlight.The sample was dried oven at about $70-80^{\circ} \mathrm{C}$ for three hours. Then it was ground to a fine powder in the pin mill. The resulting material was sieved in a size range 50-60 mesh size and used for the further process.

Experimental procedure for the adsorption Cd(II) -

An aliquot of solution containing adequate amount of $\mathrm{Cd}(\mathrm{II})$ in $\mathrm{mg}$ was taken and its $\mathrm{pH}$ was adjusted with dilute $\mathrm{HCl}$ or $\mathrm{HNO}_{3}$ or $\mathrm{H}_{2} \mathrm{SO}_{4} / \mathrm{NaOH}$ or $\mathrm{NH}_{4} \mathrm{OH}$. The total volume of the solution was made up to $50 \mathrm{~mL}$ with double distilled water and it was transferred to $250 \mathrm{ml}$ borosil beaker. Then $0.2 \mathrm{~g}$ of water chestnut adsorbent dose was added It was allowed to 
equilibrate /adsorbed for a period of time with occasional shaking. After sufficient time $5 \mathrm{ml}$ of metal ion solution was pipette out in the conical flask. After that $5 \mathrm{ml}$ of buffer solution of $\mathrm{pH} 9$ was added. Then it was titrated with $0.01 \mathrm{M}$ EDTA using PAN as an indicator. End point was determined when the color change from pink to yellow. From the volume of EDTA required the concentration of metal ion in the solution was determinedwhich remain left after adsorption. The amount of $\mathrm{Cd}(\mathrm{II})$ adsorbed was determined taking initial concentration and concentration remains after adsorption. Similar procedure was carried out for adsorption of $\mathrm{Cd}$ (II) using $0.1 \mathrm{~g}$ of pearl millet.
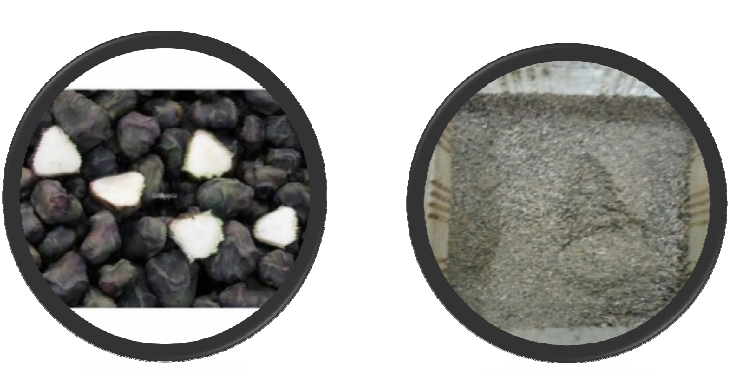

3.
4.

(1) Pearl millet image before preparation of adsorbent, (2) Pearl millet image after preparation of adsorbent, (3) \& (4) Water chestnut image before preparation of adsorbent.

\section{RESULT AND DISCUSSION:}

Adsorption measurements:

Adsorption of $\mathrm{Cd}$ (II) was carried out by studying different parameters like effect of metal ion concentration, effect of adsorbent dosage, effect of $\mathrm{pH}$, effect of temperature and effect of electrolyte

\section{Effect of metal ion concentration -}

The adsorption of Cd(II) was carried out using Water chestnut and Pearl millet as a adsorbent. The different concentration of $\mathrm{Cd}(\mathrm{II})$ metal ion was prepared like $100 \mathrm{mg}, 500 \mathrm{mg}$ and $1000 \mathrm{mg}$ per $100 \mathrm{ml}$. To study the effect of metal ion concentration $50 \mathrm{ml}$ of respective metal ion solution was taken in $250 \mathrm{ml}$ beaker Its $\mathrm{pH}$ was adjust to 6 then $0.2 \mathrm{gm}$ of Water chestnut was added it allow to get adsorbed with occasional shaking. Then after 5 minute 5 $\mathrm{ml}$ of metal ion solution was transfer in the conical flask. Then $5 \mathrm{ml}$ of buffer solution of $\mathrm{pH}$ 9 was added and it was titrate with $0.01 \mathrm{M}$ EDTA using PAN as a indicator. When colour changes from pink to yellow the volume of EDTA required was note down after fixed time interval. From the data obtained the concentration of $\mathrm{Cd}(\mathrm{II})$ was calculated also the amount of $\mathrm{Cd}(\mathrm{II})$ adsorbed and percent of adsorption was find out. Similarly the procedure is carried out using $0.025 \mathrm{~g}$ Pearl millet. The results obtained was summarized in table
Effect of metal ion concentration using water chestnut as adsorbent

Adsorption is a simplest method which is used to remove toxic metals from wastewater. Recently, the adsorption process has gained interest as a more promising method for the long term as it is seen to be a more effective and economic approach for heavy metal removal. Adsorption is a fundamental process today due to its flexibility in design and simple operation instead of having to perform adsorptions that are perceived as impractical by most conventional techniques. The term "adsorption" refers as heavy metals.

\section{Importance of method -}

The important features of the method described herein are:

* The proposed method is simple, rapid, selective and reliable.

* High costly solvent does not required for these process.

* A very low amount of bio adsorbent is required for the quantitative analysis of cadmium(II).

* Cadmium(II) can be easily absorbed in neutral slightly basis range

* The time required for the adsorption is very short. 
Table - 1. Metal ion conc. - 100 mg, adsorbent-water chestnut

\begin{tabular}{|l|l|l|l|l|l|l|}
\hline $\begin{array}{l}\text { Wt. of salt } \\
\text { solution / 100 }\end{array}$ & $\begin{array}{l}\text { Time } \\
\text { (minute) }\end{array}$ & $\begin{array}{l}\text { Vol. Of } \\
\text { EDTA } \\
(\mathrm{ml})\end{array}$ & $\begin{array}{l}\text { Conc. of } \\
\mathrm{CdCl}_{2}\end{array}$ & $\begin{array}{l}\text { Conc. of Cd } \\
\text { Absorbed }\end{array}$ & $\begin{array}{l}\text { Amount of Cd2+ } \\
\text { absorbed in ppm }\end{array}$ & $\begin{array}{l}\text { adsorption } \\
\text { of }\end{array}$ \\
\hline \multirow{5}{*}{$100 \mathrm{mg}$} & Blank & 40 & 0.08 & & & 0 \\
\cline { 2 - 7 } & 5 & 40 & 0.08 & 0 & 4.5 & 2.5 \\
\cline { 2 - 7 } & 10 & 39 & 0.07 & 0.002 & 9 & 5 \\
\cline { 2 - 7 } & 15 & 38 & 0.076 & 0.004 & 22.5 & 12.5 \\
\hline
\end{tabular}

Table-2 Metal ion conc. - 500 mg, adsorbent-water chestnut

\begin{tabular}{|c|c|c|c|c|c|c|}
\hline $\begin{array}{l}\text { W. of salt } \\
\text { solution / } 100\end{array}$ & $\begin{array}{l}\text { Time } \\
\text { (minute) }\end{array}$ & $\begin{array}{l}\text { Vol. Of } \\
\text { EDTA } \\
(\mathrm{ml})\end{array}$ & $\begin{array}{l}\text { Conc. of } \\
\mathrm{CdCl}_{2}\end{array}$ & $\begin{array}{l}\text { Conc. of } \mathrm{Cd} \\
\text { Absorbed }\end{array}$ & $\begin{array}{l}\text { Amount of } \mathrm{Cd}^{2+} \\
\text { absorbed in } \mathrm{ppm}\end{array}$ & $\begin{array}{l}\% \text { of } \\
\text { adsorption }\end{array}$ \\
\hline \multirow{6}{*}{$500 \mathrm{mg}$} & Blank & 43 & 0.083 & & & \\
\hline & 5 & 43 & 0.083 & 0 & 0 & 0 \\
\hline & 10 & 41 & 0.082 & 0.001 & 12.04 & 1.2 \\
\hline & 15 & 38 & 0.076 & 0.007 & 84.33 & 8.43 \\
\hline & 25 & 36 & 0.072 & 0.011 & 132.53 & 13.25 \\
\hline & 45 & 34 & 0.068 & 0.015 & 180.72 & 18.07 \\
\hline
\end{tabular}

Table-3 Metal ion conc. -1000 mg, adsorbent-water chestnut

\begin{tabular}{|l|l|l|l|l|l|l|}
\hline \multirow{2}{*}{$\begin{array}{l}\text { Wt. of salt } \\
\text { solution / 100 }\end{array}$} & $\begin{array}{l}\text { Time } \\
\text { (minute) }\end{array}$ & $\begin{array}{l}\text { Vol. Of } \\
\text { EDTA } \\
(\mathrm{ml})\end{array}$ & $\begin{array}{l}\text { Conc. of } \\
\mathrm{CdCl}_{2}\end{array}$ & $\begin{array}{l}\text { Conc. of Cd } \\
\text { Absorbed }\end{array}$ & $\begin{array}{l}\text { Amount of Cd } \mathrm{Cd}^{+} \\
\text {absorbed in ppm }\end{array}$ & $\begin{array}{l}\text { \% } \\
\text { adsorption }\end{array}$ \\
\hline \multirow{5}{*}{$1000 \mathrm{mg}$} & Blank & 40 & 0.08 & & & \\
\cline { 2 - 7 } & 5 & 24 & 0.048 & 0.034 & 720 & 40 \\
\cline { 2 - 7 } & 10 & 23 & 0.046 & 0.034 & 765 & 42.5 \\
\cline { 2 - 7 } & 15 & 22.5 & 0.045 & 0.035 & 7855 & 43.63 \\
\cline { 2 - 7 } & 25 & 22 & 0.044 & 0.036 & 810 & 45 \\
\hline
\end{tabular}




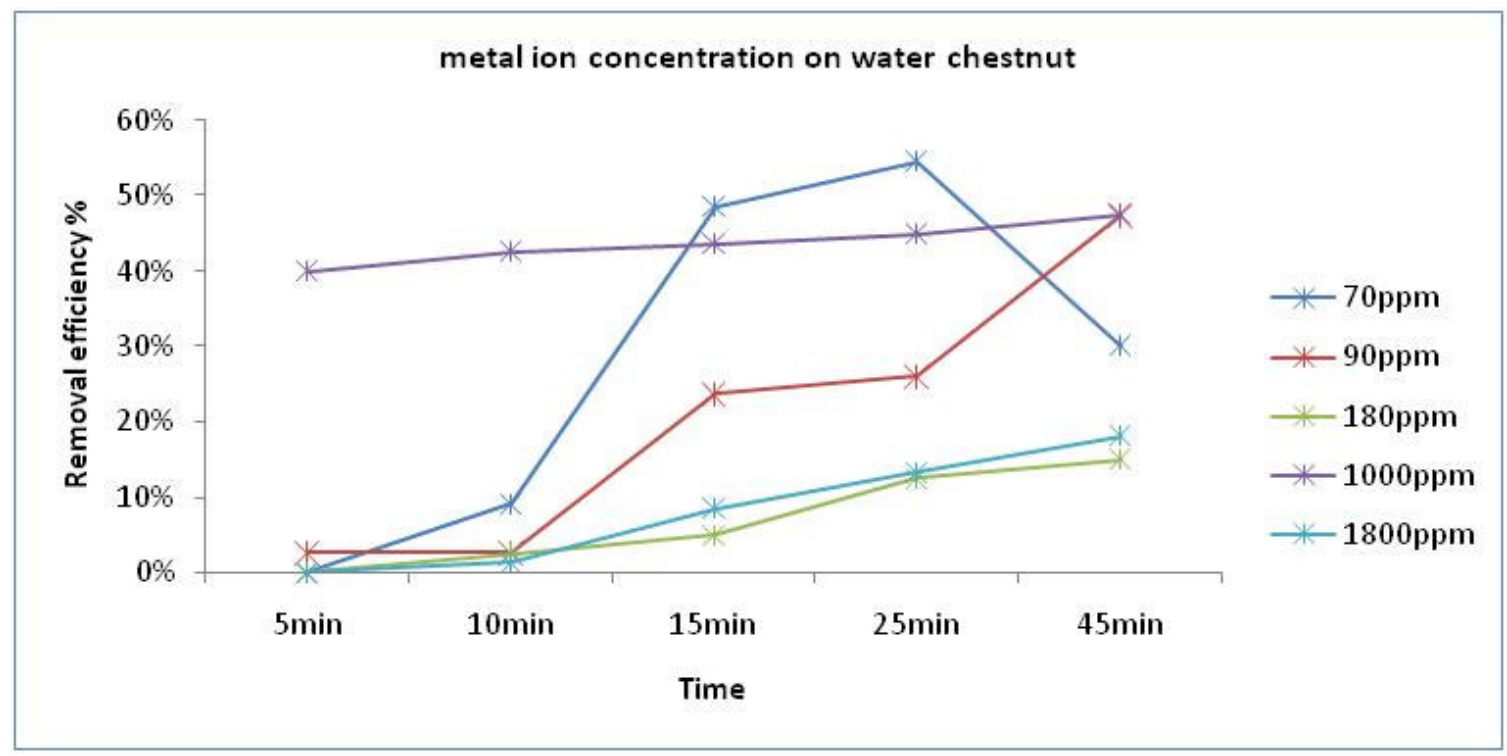

Figure -1 - Amount of adsorption of Cd (II) obtained using water chestnut adsorbent was interpreted graphically for various concentration of $\mathrm{Cd}(\mathrm{II})$. It was observed that $500 \mathrm{mg}$ of Cd(II) shows maximum adsorption

Table-4 Metal ion Conc. -100 mg, adsorbent-pearl millet, Effect of metal ion concentration using pearl millet as adsorbent

\begin{tabular}{|l|l|l|l|l|l|l|}
\hline $\begin{array}{l}\text { W. of salt } \\
\text { solution } \\
/ 100\end{array}$ & $\begin{array}{l}\text { Time } \\
(\text { minute) }\end{array}$ & $\begin{array}{l}\text { Vol. Of } \\
\text { EDTA } \\
(\mathrm{ml})\end{array}$ & $\begin{array}{l}\text { Conc. of } \\
\mathrm{CdCl}_{2}\end{array}$ & $\begin{array}{l}\text { Conc. of Cd } \\
\text { Absorbed }\end{array}$ & $\begin{array}{l}\text { Amount of } \\
\mathrm{Cd}^{2+} \\
\text { absorbed in } \\
\text { ppm }\end{array}$ & $\begin{array}{l}\% \\
\text { adsorption }\end{array}$ \\
\hline \multirow{5}{*}{$100 \mathrm{mg}$} & Blank & 42 & 0.084 & & & \\
\cline { 2 - 7 } & 5 & 42 & 0.084 & 0 & 0 & 0 \\
\cline { 2 - 7 } & 10 & 41 & 0.082 & 0.002 & 4.28 & $2.30 \%$ \\
\cline { 2 - 7 } & 15 & 38.2 & 0.076 & 0.008 & 17.14 & $9.50 \%$ \\
\cline { 2 - 7 } & 25 & 37.5 & 0.075 & 0.009 & 19.28 & $10.70 \%$ \\
\hline
\end{tabular}

Table-5 Metal ion conc. $-500 \mathrm{mg}$, adsorbent-pearl millet

\begin{tabular}{|l|l|l|l|l|l|l|}
\hline \multirow{2}{*}{$\begin{array}{l}\text { W. of salt } \\
\text { solution /100 }\end{array}$} & $\begin{array}{l}\text { Time } \\
\text { (minut } \\
\text { e) }\end{array}$ & $\begin{array}{l}\text { Vol. Of } \\
\text { EDTA } \\
(\mathrm{ml})\end{array}$ & $\begin{array}{l}\text { Conc. of } \\
\text { CdCl2 }\end{array}$ & $\begin{array}{l}\text { Conc. of Cd } \\
\text { Absorbed }\end{array}$ & $\begin{array}{l}\text { Amount of Cd }{ }^{2+} \\
\text { absorbed in ppm }\end{array}$ & $\begin{array}{l}\text { \% } \\
\text { adsorption }\end{array}$ \\
\hline \multirow{5}{*}{$500 \mathrm{mg}$} & Blank & 45 & 0.09 & & & \\
\cline { 2 - 7 } & 5 & 43.3 & 0.084 & 0.004 & 44.44 & $4.40 \%$ \\
\cline { 2 - 7 } & 10 & 41.7 & 0.083 & 0.007 & 77.77 & $7.70 \%$ \\
\cline { 2 - 7 } & 15 & 40.5 & 0.081 & 0.009 & 100 & $10 \%$ \\
\cline { 2 - 7 } & 25 & 38.4 & 0.076 & 0.014 & 155.5 & $15.50 \%$ \\
\cline { 2 - 7 } & 45 & 37.5 & 0.07 & 0.02 & 222.2 & $22.20 \%$ \\
\hline
\end{tabular}


Table-1.9 Metal ion conc. $-1000 \mathrm{mg}$, adsorbent-pearl millet

\begin{tabular}{|l|l|l|l|l|l|l|}
\hline $\begin{array}{l}\text { W. of salt } \\
\text { solution /100 }\end{array}$ & $\begin{array}{l}\text { Time } \\
\text { (minute) }\end{array}$ & $\begin{array}{l}\text { Vol. Of } \\
\text { EDTA } \\
(\mathrm{ml})\end{array}$ & $\begin{array}{l}\text { Conc. of } \\
\mathrm{CdCl}_{2}\end{array}$ & $\begin{array}{l}\text { Conc. of Cd } \\
\text { Absorbed }\end{array}$ & $\begin{array}{l}\text { Amount of Cd }{ }^{2+} \\
\text { absorbed in ppm }\end{array}$ & $\begin{array}{l}\text { \% } \\
\text { adsorption }\end{array}$ \\
\hline \multirow{5}{*}{$1000 \mathrm{mg}$} & Blank & 45.5 & 0.091 & & & \\
\cline { 2 - 7 } & 5 & 45 & 0.09 & 0.001 & 19.78 & 1.09 \\
\cline { 2 - 7 } & 10 & 44.1 & 0.088 & 0.003 & 59.34 & 3.29 \\
\cline { 2 - 7 } & 15 & 42.1 & 0.084 & 0.007 & 138.46 & 7.69 \\
\cline { 2 - 7 } & 25 & 39 & 0.078 & 0.013 & 257.14 & 14.28 \\
\hline
\end{tabular}

Figure - 2 - Amount of adsorption of Cd (II) obtained using pearl millet adsorbent was interpret graphically for various concentration of Cd (II). It was observed that $1000 \mathrm{mg}$ of Cd (II) shows maximum adsorption.

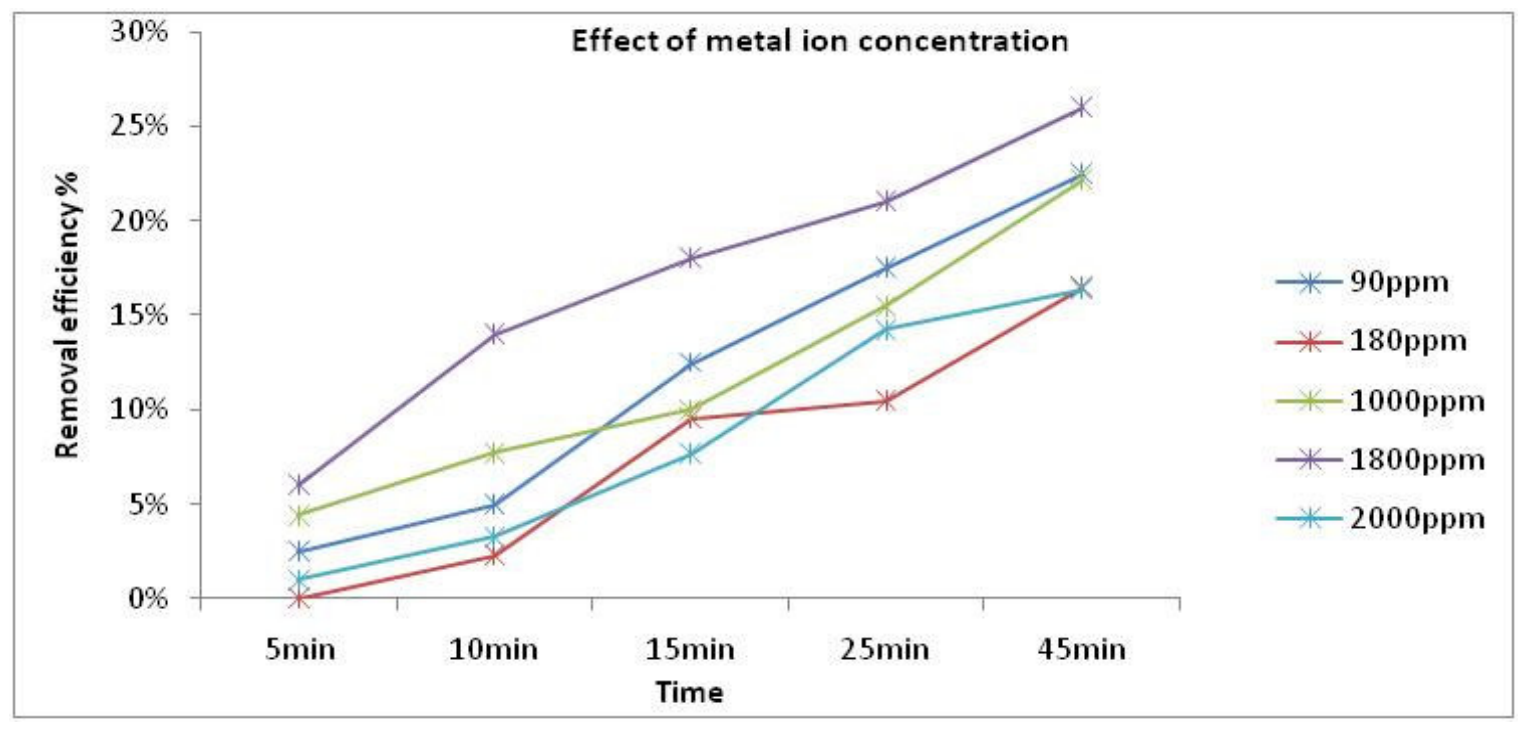

\section{REFERENCES:}

1. Jothinayagi N., Anbazhagan C., AmericanEurasian J. Sci. Res.,4 (2009) 73.

2. Shafaghat A., Salimi F., Valiei M., Salehzadeh J., Shafaghat M., Afr. J. Biotechnol., 11 (2012) 852.

3. Devaprasath P. M., Solomon J. S., Thomas B. V.,J. Appl. Sci. Environ. Sanitation., 2( 2007) 77.

4. Al-Subu M. M., Salim R., Abu-Shqair I., Swaileh K. M., Rev. Int. Contam. Ambient., 17(2001) 91.

5. Mehrasbi M. R., Farahmand Kia Z., J. Health .Environ., 1 (2008) 57.

6. Uzun I., Guzel F., Turk. J. Chem.,24 (2000) 291.

7. Kalibantionga, P. D., Ph.D., Thesis, Tshwane University of Technology, 2005.
8.SureshkumarHalnor, Int. J. Eng. Manag.,4 (2015) 19.

9. Upendra Kumar,Sci. Res. Essay., 1 (2006) 33.

$10 . \quad$ Dimple

Lakherwal,Int.J.Environ.Sci.Technol.,4(2014) 41.

11. Xiao-Xu Ho, Qing-Fang Deng and Tie-Zhen Ren, Environ. Sci.Pollut. Res.,20 (2013) 8521

12. Mervette. El Batouti, Abdel-Moneim $M$. Ahmed,Int. J.Techno.Enhancement Emerging Eng.Res., 2( 2014) 145.

13. Nethaji, A. SivasamyA. B. Mandal,Biores.Technol.,134 (2013)94.

14.Abbas Sabah Thajee, Mustafa M. Al-Faize and A. Z. Raheem,IntJ .Chem. Pharma.Techno,.5(2013) 240.

15. Suresh Kumar Halnor, MazaharFarooqui, AbdoTaher and MilindUbale, Int. J. Green Chem.,1 (2012) 169. 
16. NurdanGamzeTuran, BasakMesci, Pistachio Shells as an Adsorbent for the Removal of Zinc(II) Ion\|, Clean - Soil, Air, Water., 39 (2011) 475.

17. S. Nethaji, A. Sivasamy and A. B. Mandal,Biores. Technol.,134 (2013) 94.

18. S. S. Ahluwalia and D. Goya,Eng. Life Sci., 5(2005).

19. Juan Carlos Moreno-Piraján, And LilianaGiraldo, E-J. Chem., 9 (2012) 926

20. ShidvashDowlatshahi, Ahmad Reza HaratinezhadTorbati, MahshidLoloei, Environ..Health Eng.Manage.J., 1(2014) 37.

21. Arunkumar C, Perumal R, Lakshmi Narayanan $\mathrm{S}$ and ArunkumarJ, Int. J. $A d v$. Biotech. Res., 15(2014) 325.

22. Kamal Rana, Mitali Shah, NileshLimbachiya, Int. J. Adv. Eng. Res. Sci.1 (2014)55.

23. A. Anandan and T. Janakiram, J. Chem. Pharma. Res,. 4 (2012) 2900.

24. RuzhenXie, Hui Wang, Yao Chen, and Wenju Jiang, Environmental Progress \& Sustainable Energy., 3 (2013) 688.
25.P K Baskaran, 2B R Venkatraman, 3M Hema and 4S Arivoli*, J. Chem. Pharm. Res., 2(5) (2010) 642 .

26. Broadley, M.R., White, P.J., Hammond, J.P., Zelko I. and Lux, A., New Phytologist, 173 (2007) 677.

27.Cadmiun in Kirk-Othmer Encyclopedia of Chemical Technology,(John Wiley \& Sons), Inc. 1999, revision to be published 2010.

28.Stenstrom, S., "Proc. ISEC'83", Colarado, (1983), 197.

29. Tijoe, T.T., Durville, P.F.M., Van Rosmalen, G.M., Solvent Extr. Ion Exch., 7 (1989) 435.

30. Friberg, L., Elinder, C.G. and Kjellstrom, T., Cadmium, World Health Organization, (Geneva), (1992).

Ulman's Encyclopedia of Industrial Chemistry, (Wiley-VCH, Weinheim), (2003).

31. Reinhardt, H., Proc. Int. Conf. on Hazard. Waste "Sources, effects and Management", Cairo, Egypt, (1998).

32. Safarzadeh, M.S., Bafghi, M.S., Moradkhani, D. and Ilkhchi, M.O., Miner. Eng., 20 (2007) 211. 